\title{
Chapter 8 \\ Professional Assessment and Development Induction Program: An Application of the BRiTE Project to the Spanish Context
}

\section{Gloria Gratacós, Montse Giménez, Juanjo Mena, and Monika Ciesielkiewicz}

\begin{abstract}
Research has highlighted the importance of the first years of teaching as they have a great impact on teachers' career longevity. Therefore, inspired by the BRITE project, we developed the Professional Assessment and Development (PAD) Induction Program with the objective of helping novice teachers develop resilience strategies for successfully navigating the difficult situations they may face in their first years of teaching. The PAD Induction Program also offers training for mentors in schools to assist them to guide and support new teachers. The program consisted of online content and activities aimed at encouraging novice teachers to reflect on their current situation and possibilities for improvement. There were also face-to-face seminars, distributed throughout the program, as well as specific seminars where novice teachers and mentors worked together. A total of 112 participants participated in the PAD program. To assess novice teachers' resilience and commitment to teaching, participants were invited to complete the Multidimensional Teacher Resilience Scale (MTRS) and the Teacher Commitment Scale. Results showed that the PAD program had helped them in their integration, confidence, and stress control through the development of teacher resilience dimensions.
\end{abstract}

Keywords Novice teachers $\cdot$ Teacher resilience $\cdot$ Induction plans $\cdot$ Mentoring

The original version of this chapter was revised: Error in link has been corrected as "http://www. entree-online.eu/". The correction to this chapter is available at https://doi.org/10.1007/978-98115-5963-1_19

G. Gratacós $(\bowtie) \cdot$ M. Ciesielkiewicz

Villanueva University, Madrid, Spain

e-mail: ggratacos@villanueva.edu; gloriagratacos@gmail.com

M. Ciesielkiewicz

e-mail: monikacies@gmail.com

M. Giménez

C.U. Cardenal Cisneros, Madrid, Spain

e-mail: montse.gimenez@cardenalcisneros.es

J. Mena

University of Salamanca, Salamanca, Spain

e-mail: Juanjo_mena@usal.es 


\subsection{Introduction}

In recent years, the demands placed on educational institutions and teachers have increased considerably (Day and Gu 2007; Mansfield et al. 2016). Teachers are pressured to improve academic outcomes of their students and to overcome the shortcomings of family environments, school administrations, and society in general. They are expected to respond more effectively to social and economic demands and help transform education, often under conditions of great difficulty. Teachers have to teach students with very diverse needs and to be up to date on curricular, pedagogical, evaluation, and digital learning innovations (TALIS 2013). This can be a significant source of stress for more experienced teachers and even more so for those who join the teaching profession, who are usually expected to assume almost the same responsibilities than more experienced teachers causing them "high level of stress, emotional distress, professional burnout and even attrition” (Leroux 2018 p. 107).

Different studies have found that the attrition rate of teachers is relatively higher when compared to other professions (Ingersoll and Strong 2011). In case of novice teachers, lack of well-being can lead to departure from the teaching profession (Ávalos and Valenzuela 2016; Kessels 2010; Kyriacou 2010). In fact, the attrition rate of recently graduated teachers is even higher, reaching between $30 \%$ and $50 \%$ of teachers leaving the education sector during the first five years (Ingersoll and Strong 2011).

The challenges caused by working conditions (i.e., salary or insufficient resources in the classroom), classroom characteristics (i.e., excessive ratio or student's misbehavior), or organizational factors of the school environment (i.e., lack of support or low participation in decision making) may explain some teacher attrition (Stromquist 2018). Moreover, Rots et al. (2007, p. 544) state that "the roots of teacher attrition can be found in initial teaching commitment and the quality of early teaching experiences." Commitment to teaching can be understood as a "degree of psychological attachment to the teaching profession" (Coladarci 1992, p. 323). These studies confirm the importance of improving the experiences of early career teachers transitioning to the profession (European Commission 2010).

Induction programs aim to ease the transition into the profession and provide necessary professional learning for teachers in the early career stages. The term induction can be conceptualized as "the process of formal assistance for the beginning teacher" (Greenlee and Dedeugd 2002) consisting of "activities designed to support new teachers" (OECD 2017). Induction includes "a range of diverse initiatives such as mentoring, instructional coaching, teaching residency, and school-university partnerships" (Paniagua and Sánchez-Martí 2018, p. 31). The fact that induction involves different activities may explain how these programs vary considerably between countries (European Commission/EACEA/Eurydice 2018). Strategies dealing with feelings and attitudes are necessary for novice teachers to emerge reinforced from each challenging situation and to grow professionally. In this regard, it is crucial that novice teachers participate in induction programs that allow increased support as they integrate into the classroom and into the school organization (European Commission 
2010; European Commission/EACEA/Eurydice 2018) and undoubtedly, to have the emotional and personal support necessary for their well-being (Gold 1996, cited in Kessels 2010).

The research has found significant support on the effectiveness of these programs in three fundamental aspects: commitment and retention of the teaching staff, teaching practices, and student performance (Ingersoll and Strong 2011). Additionally, induction programs contribute to the well-being of novice teachers (Kessels 2010), reducing loneliness (Chubbuck et al. 2001), and offering support which is highly valued by the program's participants (Kelley 2004), even when it is only provided online (DeWert et al. 2003). Among the key elements of induction programs, Ingersoll and Smith (2004) distinguish the most significant forms of support for novice teachers, such as having a mentor from the same area of knowledge, establishing common study programs with other teachers of the same subject, maintaining regular collaboration with other teachers and being part of an external network of teachers.

Although no data on teacher attrition in Spain is currently available, there is considerable concern about teacher burnout since research highlights rates higher than 30\% (Aris Redó 2009). Evidence also shows that the number of teachers who suffer from anxiety in recent years has been increasing (Asociación Nacional de Profesionales de la Enseñanza 2018).

As in other contexts, novice teachers in Spain find it difficult to respond to the demands of the classroom and school environment, which can lead to low selfefficacy, stress, and sometimes burnout (Aris Redó 2009; Leroux 2018; Skaalvick and Skaalvick 2011). It is also worthwhile to mention other difficulties inherent to the teaching profession in the Spanish context such as the loss of authority, bullying, and lack of family involvement (Pedró et al. 2008).

According to Borman and Dowling (2008, p. 399), "discovering the ways in which pre-service, internship, and professional development experiences can be structured to help teachers during the crucial first five years is a critical research, policy, and program development initiative for the future."

\subsection{Teacher Induction in Spain}

The Spanish education system is comprised of pre-primary, primary, secondary, and higher education levels. Basic education is compulsory and tuition-free from 6 to 16 years (6 years in the primary level and 4 years in the lower secondary education). At the end of the fourth secondary year, students may choose to continue with secondary education, to enter into university degrees programs, or take a basic vocational training. Students can attend a public school (67.3\% of the total population of pre-primary, primary, and secondary education), a partially government-funded independent school (25.9\% of the total), or a private school $(6.9 \%$ of the total) (MECD 2018). 
In the Spanish context, it is necessary to distinguish between the access to the teaching profession in public schools from the private or partially governmentfunded independent schools. In public schools, teachers who pass professional entrance exams have access to the teaching profession, and usually have specific training of varied duration and content. These exams cover teacher training, equality, and prevention of gender violence. The duration of the training is usually no less than $20 \mathrm{~h}$, although there is a lack of consistency in approaches to induction. In fact, some communities do not offer any type of training (European Commission/EACEA/Eurydice 2018). Theoretically, during this first phase of training, teachers have a teacher-tutor who advises, informs, and guides the novice teacher in the process of transition into the educational institution and in the performance of their teaching practice. They can also participate in any classes taught by the mentor teacher with a frequency that varies in each community. Based on the information collected, the mentor teacher prepares a report assessing his or her novice teachers' teaching skills.

Although there is no systematic and consistent data, some institutions in the private sector develop host programs, or at least, undertake some actions with the aim of facilitating the integration of novice teachers (e.g., interviews with the director, assignment of a fellow tutor). The contents covered have a merely informative character and serve to convey the mission and character of the educational center, as well as organizational and operational aspects.

According to the TALIS 2018 report, in Spain, $75 \%$ of primary school teachers and $74 \%$ of secondary teachers did not participate in any induction program in their first school. Only one out of every three schools offer a formal induction program for novice teachers and no more than 50\% were engaged in informal initiation activities. The activities reported in induction programs and the grade of teachers' participation is reported in Table 8.1 .

It is interesting to note that the activities below the OECD-30 average offered in Spain are mainly focused on teacher reflection, whether through interaction with others (principal, mentor, other teachers) or using activities such as portfolios and/or work diaries. Reduction of teaching load is very rarely considered in the Spanish context.

Therefore, it seems important that induction programs include initiatives designed to increase resilience, since it would allow teachers to develop personal characteristics related to a positive attitude and self-confidence when dealing with a wide range of changes, pressures, and demands in their daily work as teachers (Kyriacou 2010).

\subsection{Induction, Resilience, and Mentoring}

The underpinning literature of this study is drawn from the fields of teacher resilience and early career teacher mentoring. The study aims at easing the transition into the profession for novice teachers, providing them with the necessary professional learning through induction programs. 
Table 8.1 Percentage of Primary and Secondary teachers who report being offered the following activities as a part of a professional initiation program

\begin{tabular}{l|l|l}
\hline & Primary school & Secondary school \\
\hline In-person courses or seminars & 79 & 68 \\
\hline Courses or seminars online & 34 & 23 \\
\hline Online activities & 27 & 31 \\
\hline $\begin{array}{l}\text { Scheduled meetings with the principals and/or experienced } \\
\text { teachers }\end{array}$ & $76^{\mathrm{a}}$ & $71^{\mathrm{a}}$ \\
\hline Monitoring by the director and/or experienced teachers & $68^{\mathrm{a}}$ & $61^{\mathrm{a}}$ \\
\hline Networking or collaboration with other novice teachers & 50 & 50 \\
\hline Co-teaching with experienced teachers & $67^{\mathrm{a}}$ & $40^{\mathrm{a}}$ \\
\hline Portfolios and work diaries & $40^{\mathrm{a}}$ & $28^{\mathrm{a}}$ \\
\hline Reduction of teaching load & $11^{\mathrm{a}}$ & $9^{\mathrm{a}}$ \\
\hline General or administrative initiation & $26^{\mathrm{a}}$ & $36^{\mathrm{a}}$ \\
\hline
\end{tabular}

${ }^{\text {a }}$ Data below the UE-23 y OCDE-30 average

Source Prepared by the authors based on TALIS report (2018)

Teaching experiences at the initial stages have a great impact on the rest of a career (Day and Gu 2007). Nevertheless, studies on resilience of pre-service and novice teachers are limited (Morgan 2011; Mansfield et al. 2016). Therefore, it is crucial to study early career teacher resilience as it is an instrumental and decisive career phase.

Resilience is described in current literature as a complex, multifaceted, idiosyncratic, and dynamic construct (Beltman et al. 2011; Mansfield et al. 2012). Ungar (2012) defines resilience as "a set of behaviours over time that reflect the interactions between individuals and their environments, in particular the opportunities for personal growth that are available and accessible" (p. 14). Moreover, Boldrini et al. (2018) state that resilience refers to positive and functional adaptation and that the main indicators are a sense of positive engagement with the profession and a sense of perceived effectiveness. Day and Gu (2014) oppose limiting resilience to just bouncing back from adverse and challenging circumstances and emphasize the importance of developing strategies to sustain teacher commitment and effectiveness in their daily activities.

Being aware and enhancing protective factors, both individual (personal attributes, self-efficacy, coping skills, teaching skills, professional reflection and growth, and self-care) and contextual (school/administrative support, mentor support, support of peers and colleagues, working with the students, characteristics of pre-service program, and support of family and friends) can help to develop teacher resilience (Beltman et al. 2011). Also, several researchers discern various risk factors for teacher resilience, among which the most frequent are personal risk factors such as negative feelings, low self-efficacy or self-confidence, difficulty to balance professional and personal life, low professional competences and abilities, as well as certain environmental risk factors, for example, stress conditions such as heavy workload, difficult 
relationships with students or parents (Beltman et al. 2011; Leroux and Théorêt 2014; Mansfield et al. 2012). Regarding Spain, some additional factors should be added such as the loss of teachers' authority not only with parents but also with students as well as the lack of teacher assistants in the classrooms (Vicente de Vera 2017).

It is important that novice teachers are aware of the protective factors that could help them develop strategies to enhance their resilience. It may also be useful to build strategies that take into consideration different dimensions of resilience. Mansfield et al. (2012) propose a four-dimensional framework of teacher resilience which is comprised of emotional, motivational, social, and profession-related dimensions of resilience. The emotional dimension focuses on the affective aspects of teaching, emotion management, taking care of one's own well-being, and handling stress. The motivational dimension encompasses motivation, enthusiasm, confidence, persistence, and establishing clear and attainable goals. The social dimension is comprised of building a support network, strong interpersonal and communication skills, seeking assistance, and problem-solving. The profession-related dimension involves various aspects of teaching practice such as preparation, organization, self-reflection, engagement in student's learning, and effective teaching skills.

Some education programs include professional training of novice teachers with the help of a mentor chosen from the most experienced teachers (Marcelo García 2009) as a useful way of enhancing teaching and learning (Bressman et al. 2018). According to the data from the TALIS report (2018), only $15 \%$ of novice Primary school teachers and $16 \%$ novice Secondary school teachers in Spain were assigned a mentor, compared to $26 \%$ in the OECD average or $34 \%$ in the EU average. The majority of school principals consider that tutoring with teachers (both Primary and Secondary) helps to improve pedagogical competence, collaboration with teachers, strengthens professional identity, supports teachers with less experience, and improves overall student performance. Despite the general perception that mentors are key figures in induction programs, mentor training is still an under-researched topic. However, literature clearly highlights the importance of mentor preparation as a priority in the area of policymaking (TALIS 2018).

\subsection{The Intervention Program}

Research not only highlights the importance of induction programs that include activities to support new teachers transition into the profession (TALIS 2018) but also includes mentoring assistance, as well as the need to develop resilience with novice teachers in the first years of their teaching experience. These studies drew our attention and interest to programs developed in different countries that could be useful for novice teachers in Spain. Therefore, the Professional Assessment and Development (PAD) Induction Program presented below, originates from the need to support novice teachers in the beginning of their professional career. The PAD program offered a complete training with diverse and interconnected training strategies, which allowed flexibility to adapt it to the needs of each novice teacher. It 
also included training for mentors who were willing to help novice teachers in their educational institutions. The training took into account their professional experience and offered them new tools and resources. The PAD program is based on the materials developed by another program called ENhancing Teacher REsilience in Europe (ENTREE), ${ }^{1}$ an EU-funded project and the BRITE ${ }^{2}$ Project, an Australian interuniversity project (see Chap. 3). Both programs aim to develop teachers' resilience as a response to the growing demands of rapidly changing school environments.

This Spanish program emerged as an initiative of Villanueva University Center, later joined by Cardenal Cisneros University Center (CCUC). The objectives of the program were the following:

- Facilitating the integration of novice teachers in educational institutions.

- Offering support and advice to assist novice teachers in their training and teaching activities to increase their confidence as teachers.

- Mentoring of novice teachers in their transition to the profession.

- Developing effective learning strategies for the acquisition of skills that can be transferred to the different areas of personal, social, and professional development.

- Offering resources to teacher's mentors to help them successfully carry out their task.

The PAD program began in the 2016-17 academic year and was offered to several educational institutions with which Villanueva has been collaborating. Potential participants could have a maximum of two years of teaching experience in those schools. The program provided online theoretical and practical modules, face-toface sessions in which practical cases were worked on in joint groups of novice teachers and mentors, as well as a face-to-face training for mentors. Thus, the PAD program was composed of-

a. Seven online modules. The first six modules were adapted from the ENTREE program and inspired by the BRITE program with the permission of all authors. We also incorporated a new module on relationship with students' families since it is a challenging issue for novice teachers. The seven thematic blocks were

1. Resilience

2. Building relationships

3. Aspects of effective teaching

4. Classroom management skills

5. Emotional well-being

6. Stress management

7. Relationship with students' families.

The modules contained a theoretical part, as well as self-reflection activities. These activities were shared with and corrected by university professors who coordinate the PAD program. Each month participants engaged with a different

\footnotetext{
${ }^{1}$ ENTREE (n.d.). Enhancing teacher resilience in Europe. http://www.entree-online.eu/. Accessed 25 November 2018. See: Silva et al. (2018).

${ }^{2}$ BRITE (n.d.). Building resilience in teacher education. http://www.entree-online.eu/. Accessed 25 November 2018. See: Beltman et al. (2018).
} 
module, and a face-to-face meeting was held to carry out a series of practical activities, such as cases, workshops, role-plays, and simulations. The participants were organized into heterogenous groups that included teachers and mentors from different schools. Sharing their experiences and concerns in these groups was considered a great asset for the program participants.

b. In-person training for mentors who would be assisting novice teachers. An advisory board was created to support the mentors. It consisted of four university professors who were experts in practicum and three professors from different educational institutions who were chosen from among the best practicum tutors who regularly collaborate with Villanueva University Center. They advised on the design of a series of semi-structured interviews, and a series of training seminars was designed and taught throughout the whole school year with a total of $24 \mathrm{~h}$ training. The contents were:

Resilience and Wellbeing. The goal was to train teachers to overcome adversity, emerge strengthened, believe in oneself and, consequently, increase protective factors.

Intelligent communication. The goal was for participants to become more assertive, and for mentors to use coaching tools for constructive feedback.

Participants committed to complete the online course with all the required activities and to attend in-person sessions held every month. They also committed to two interviews with a mentor during the course period. Their mentor also observed their teaching and provided constructive feedback.

\subsection{Method}

A total of 112 novice teachers participated in the PAD program, 73 females $(65.2 \%)$ and 39 males (34.8\%). Participants taught in four educational levels: 20 (17.9\%) were in early childhood education; 48 (42.9\%) in Elementary Education; 55 (49.1\%) in Lower Secondary school; and 11 (9.8\%) in Upper Secondary school. Ethics permission for the study was granted by Villanueva University and all participants were volunteers.

In order to assess novice teachers' resilience and commitment to teaching, participants were invited to complete the Multidimensional Teacher Resilience Scale (MTRS) and the Teacher Commitment Scale before starting the program, providing them an online link to the questionnaire. Both scales are part of the Teacher Resilience Self-Reflection (TRSR) questionnaire developed and empirically tested by Wosnitza et al. (2018). The MTRS consists of 26 items that assess the four dimensions of teacher resilience (Mansfield et al. 2012): (a) Professional (4 items; e.g., I am well organized in my school work); (b) Motivational (12 items; e.g., When I make mistakes at school, I see these as learning opportunities); (c) Social (4 items; e.g., When I am unsure of something I seek help from colleagues); and (d) Emotional (4 items; e.g., 
When something goes wrong at school, I don't take it too personally). The Teacher Commitment is a 5-item scale (e.g., "I feel pleased that I decided to be a teacher"). Both of them use a Likert scale from 1 (strongly disagree) to 5 (strongly agree).

At the end of the program, participants were invited to answer an online questionnaire where they could evaluate their satisfaction with the program (5-point Likert scale) as well as provide comments about the usefulness of the induction program and how it had helped their integration, confidence, and stress management.

\subsection{Results}

\subsubsection{Novice Teachers' Resilience and Commitment to Teaching}

All the participants of the PAD program implemented the MTRS and Teacher Commitment questionnaires. Main results of both questionnaires are shown in Table 8.2.

The mean scores in all scales are around 4 (out of 5), with the exception of commitment, with a mean that is close to the maximum (4.705). The emotional dimension had the lowest mean score. The Standard Deviations (SD) are low, indicating that there is little variability within the sample.

The statistical relationship between teacher resilience and commitment was tested as shown in Table 8.3. Commitment, understood as the capacity of dedicating time and effort for the profession, can be a relevant aspect for teachers to better cope with the profession. As explained above, resilience was divided into four dimensions: (a) professional; (b) emotional; (c) motivational; and (d) social.

Results show that teacher commitment is significantly related with the professional dimension of teacher resilience $(r=0.252 ; p=0.005)$ which focuses on self-reflection in their teaching practice. The same applies to the social aspects of

Table 8.2 Descriptive statistics and reliability of the TRSR questionnaire: resilience dimensions and commitment

\begin{tabular}{l|l|l|l|l|l|l}
\hline & Minimum & Maximum & Mean & Std. deviation & Variance & Cronbach alpha \\
\hline TR PROF & 3.00 & 5.00 & 4.41 & 0.458 & 0.210 & 0.651 \\
\hline TR EMOT & 2.75 & 5.00 & 4.08 & 0.531 & 0.283 & 0.616 \\
\hline TR MOT & 3.42 & 5.00 & 4.38 & 0.372 & 0.139 & 0.815 \\
\hline TR SOC & 3.17 & 5.00 & 4.25 & 0.464 & 0.216 & 0.781 \\
\hline COMMITMENT & 3.00 & 5.00 & 4.70 & 0.461 & 0.213 & 0.856 \\
\hline
\end{tabular}

TR PROF: Teacher Resilience. Professional dimension TR EMOT: Teacher Resilience. Emotional dimension TR MOT: Teacher Resilience. Motivational dimension TR SOC: Teacher Resilience. Social dimension 
Table 8.3 Pearson correlation scores on the TRSR questionnaire resilience dimensions and commitment

\begin{tabular}{l|l|l|l|l|l}
\hline & TR_PROF & TR_EMOT & TR_MOT & TR_SOC & COMMIT \\
\hline \multirow{2}{*}{ TR_PROF } & 1 & 0.605 & 0.653 & 0.574 & 0.252 \\
\cline { 2 - 6 } & & 0.000 & 0.000 & 0.000 & 0.005 \\
\hline \multirow{2}{*}{ TR_EMOT } & & 1 & 0.536 & 0.544 & 0.165 \\
\cline { 2 - 6 } & & & 0.000 & 0.000 & 0.068 \\
\hline \multirow{2}{*}{ TR_MOT } & & & 1 & 0.744 & 0.305 \\
\cline { 2 - 6 } & & & & 0.000 & 0.001 \\
\hline COMMIT & & & & 1 & 0.179 \\
\hline
\end{tabular}

Correlation is significant at the 0.01 level (2-tailed)

resilience, when coping with colleagues' interactions at the school $(r=0.179 ; p$ $=0.048$ ). Moreover, commitment strongly correlates with the motivational level of resilience $(\mathrm{r}=0.305 ; p=0.001)$, but it is not significantly linked to the emotional side $(r=0.165 ; p=0.068)$.

\subsubsection{Participants' Satisfaction with the PAD Program}

At the end of the program, $70 \%$ of the total of the participants completed the satisfaction questionnaire. The average degree of satisfaction of the modules was as follows:

- Satisfaction with the contents: 3.97

- Satisfaction with the face-to-face seminars: 3.98

- Satisfaction with the mentor: 4.49 .

Participants were also invited to provide comments about the mentoring process such as the usefulness of the interviews with their mentors, the classroom observations, and the feedback from them as well as the utility of the contents and activities they had worked.

Regarding the program content, novice teachers remarked on the opportunity to reflect on their own performance. They also pointed out the practical nature of the program. They valued very positively certain activities, such as feedback from class observations, the diary in which they registered emotions, simulations, and case studies.

- "The face-to-face sessions have been very motivating since they lead to sharing experiences among all the teachers who participated in the program. This helps to 
establish relationships between the previous PAD sessions and their application in the classroom."

Regarding mentoring, the PAD participants valued positively the support provided by mentors:

- "It helped me get positive feedback and critically analyze my way of teaching classes. I outlined those aspects that I had to polish and set a series of objectives to meet."

The frequency of meetings was very diverse depending on the availability of the mentor and conducted with different strategies, such as interviews or feedback on class observations in person or recorded which took place in $81 \%$ of cases.

Ninety-one percent of the respondents expressed that they would recommend the PAD program to other novice teachers and even to those with more professional experience since it allows for continued learning and improved relationships with other professionals.

- "Yes. I would recommend it to all teachers since it addresses very current topics in Education. In addition, it fosters opening to other perspectives and promotes reflection, which I consider fundamental to improve our teaching."

In order to assess the degree of integration and well-being of the participants, the following questions were asked: (1) To what extent has the PAD program helped you to be more integrated in the school? (2) To what extent has the PAD program helped you to be more confident as a novice teacher? (3) To what extent has the PAD program contributed to increase or decrease your stress as a novice teacher?

The first analysis was regarding whether the PAD program had or not helped with those three aspects. Results showed that $77 \%$ reported that the program had helped them in their degree of integration in the school. From the participants that reported the program not to be of any help (23\%), $70 \%$ stated that they were already integrated in the school since it was their second year working there, or they were school alumni. Eighty-six percent reported that the PAD program had helped them to be more confident as a teacher, and $79 \%$ reported that the program had helped them manage their stress.

The open-ended questions were initially inductively and independently manually coded by two researchers (one from each institution). The results were compared for consistency, and the analysis was refined going back to the research framework on protective factors and teacher resilience dimensions in order to clearly define and combine the codes. Categories and frequency counts were organized within and across each group's set of responses. The analysis of these responses was used to establish the aspects that participants highlighted when reporting on how the PAD program had helped them with their integration, confidence, and stress control as described in Table 8.4.

Results in Table 8.4 show how the PAD program helped novice teachers' integration in the school through strategies focused on the social and professional teacher resilience dimensions. Professional, social, and motivational dimensions were found 


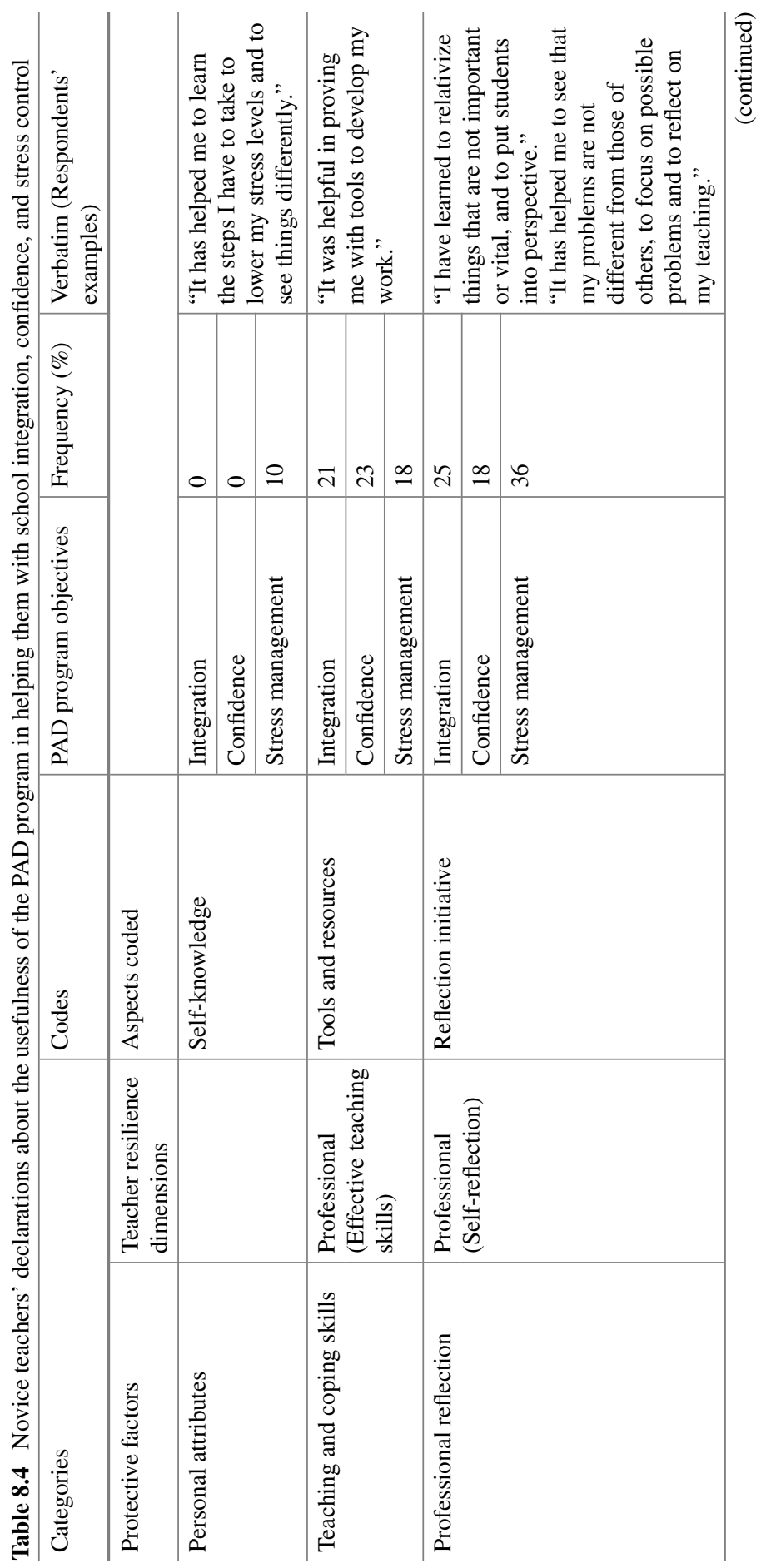




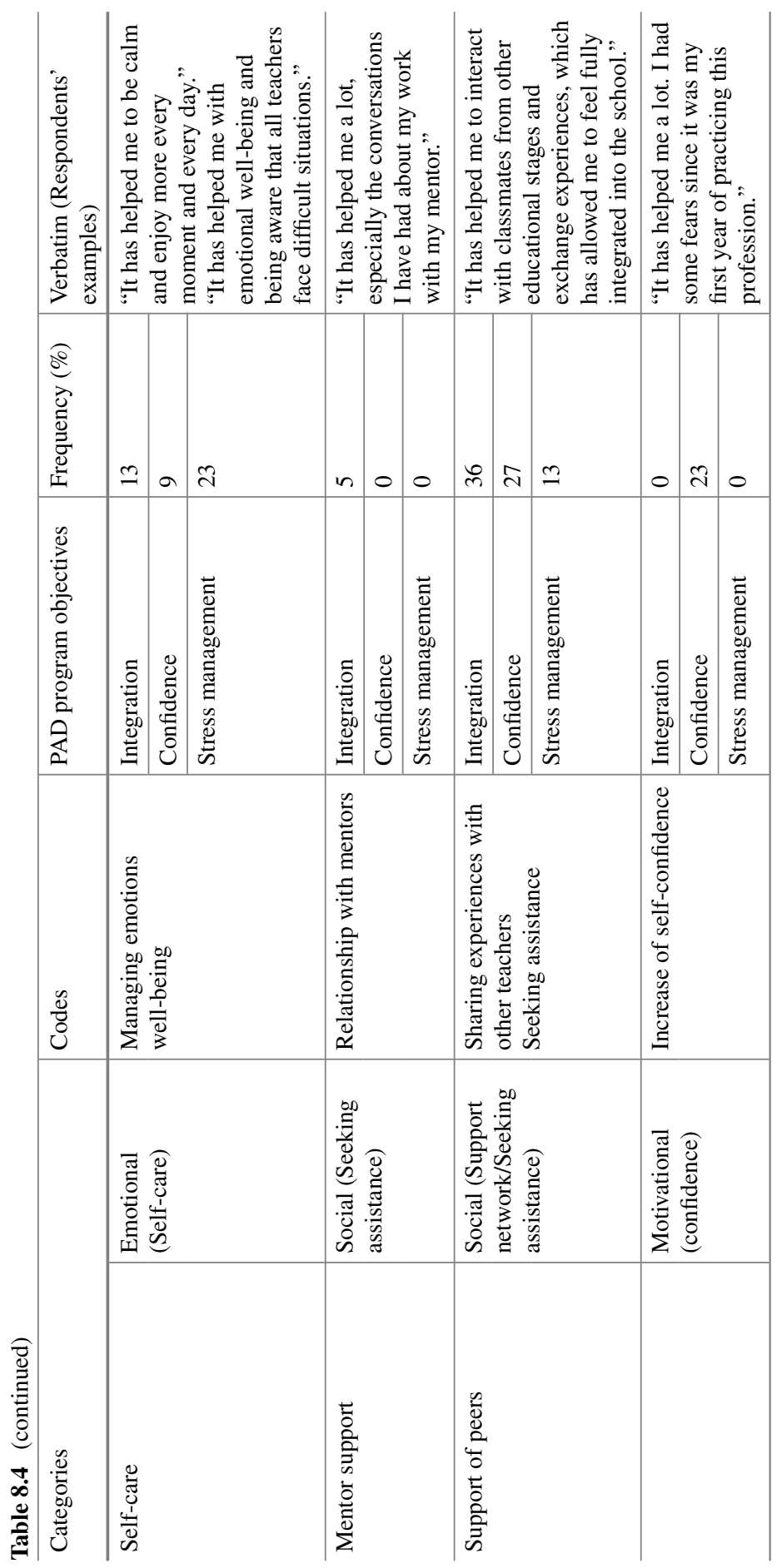


to be critical in enhancing their confidence as teachers. Professional and emotional dimensions were reported to be more useful to manage stress among the novice teachers.

\subsection{Discussion and Conclusions}

The purpose of this chapter was to describe the PAD Induction Program based on the work of the ENTRÉE and BRITE programs that are aimed at developing resilience in new teachers, with the support of mentors as a unique aspect of the program and assess the possible influence of resilience on teacher commitment. The PAD program also comprises many of the activities highlighted by the TALIS report (2018) such as in-person courses or seminars, courses and activities online, scheduled meetings with experienced teachers (mentors), networking with other novice teachers, portfolios, and work diaries. It also includes school-university partnerships to assist novice teachers. In sum, it is a holistic program that focuses on the novice teachers' well-being and stresses the importance of protective factors for the development of teacher resilience such as support seeking, social links, motivational and emotional development, and professional reflection.

Results from the participants' responses showed that the PAD program had helped them in their integration, confidence, and stress control through the development of personal and contextual protective factors as well as teacher resilience dimensions. They especially highlighted the chance to reflect on critical situations, recognizing both progress and mistakes that needed correction, as well as to experience working collaboratively with other teachers, which according to Avalos and Valenzuela (2016) seem to protect novice teachers from frustration, excessive stress, and lack of capacity to search for solutions. Novice teachers also appreciated the tools and resources provided to enhance their teaching and coping skills. It is interesting to pinpoint how different teacher resilience dimensions interact with the PAD program's objectives.

The results of this study indicate that professional, social, and motivational dimensions of teacher resilience are significantly correlated with commitment. Being a correlational study, causality cannot be inferred. Nevertheless, results support the idea that resilience could be a possible indicator of commitment to the profession (Gu and Day 2013; Tait 2008). Therefore, taking into account resilience development in Teacher Education programs and induction plans could be helpful in addressing teacher retention. Also mentoring could play an important role in the early teaching career to enhance teacher resilience. Moreover, it seems necessary to work on the four dimensions of teacher resilience in order to promote novice teachers' school integration, confidence, stress control and, as a result of these, commitment. Providing opportunities for teachers' collaborative work, professional reflection, and making them aware of their crucial and unique role in education could be determining factors in teacher retention.

Some limitations of the study are its small sample size (112 participants) and limited generalizability beyond the Spanish context. The fact that qualitative data was 
based on open-ended question evaluation might also be limiting. For further research, it would be useful to include interviews in order to better understand the process and impact of induction on their resilience competences development. Additionally, it would be interesting to collect data on MTRS and Teacher Commitment scales after the program and analyze the differences to evaluate the PAD program; as well as to explore whether the frequency of meetings with mentors influences in some way novice teachers' degree of integration in and/or satisfaction with the teaching experience. Since the PAD program offers resources to teacher's mentors, it would be of interest to include mentors' evaluation of the program and program's mentoring resources. Given the complexity of the dimensions under study in novice teacher resilience, future lines of research could also examine not only including them in induction plans and describing the relations between them, but also unlocking the intermediate variables that mediate in the professional identity construction at early stages of their teaching career.

\section{References}

Aris Redó, N. (2009). El síndrome del burnout en los docentes. Doctoral dissertation, Universidad Internacional de Cataluña, Spain.

Asociación Nacional de Profesionales de la Enseñanza. (2018). Memoria estatal del defensor del profesor. Curso 2017-18.

Ávalos, B., \& Valenzuela, J. (2016). Education for all and attrition/retention of new teachers: A trajectory study in Chile. International Journal of Educational Development, 49, 279-290. https:// doi.org/10.1016/J.IJEDUDEV.2016.03.012.

Beltman, S., Mansfield, C., \& Price, A. (2011). Thriving not just surviving: A review of research on teacher resilience. Educational Research Review, 6(3), 185-207. https://doi.org/10.1016/j.edu rev.2011.09.001.

Beltman, S., Mansfield C. F., Wosnitza, M., Weatherby-Fell, N., \& Boadley, T. (2018). Using online modules to build capacity for teacher resilience. In M. Wosnitza, F. Peixoto, S. Beltman, \& C. F. Mansfield (Eds.), Resilience in education: Concepts, contexts and connections (pp. 237-253). Cham: Springer.

Boldrini, E., Sappa, V., \& Aprea, C. (2018). Which difficulties and resources do vocational teachers perceive? An exploratory study setting the stage for investigating teachers' resilience in Switzerland. Teachers and Teaching, 25(1), 125-141. https://doi.org/10.1080/13540602.2018. 1520086.

Borman, G., \& Dowling, N. (2008). Teacher attritionattrition and retentionretention: A metaanalyticmeta-analytic and narrative review of the research. Review of Educational Research, 78(3), 367-409. https://doi.org/10.3102/0034654308321455.

Bressman, S., Winter, J. S., \& Efron, S. E. (2018). Next generation mentoring: Supporting teachers beyond induction. Teaching and Teacher Education, 73, 162-170. https://doi.org/10.1016/j.tate. 2018.04.003.

Chubbuck, S. M., Clift, R. T., Allard, J., \& Quinlan, J. (2001). Playing it safe as a novice teacher: Implications for programs for new teachers. Journal of Teacher Education, 52(5), 365-376.

Coladarci, T. (1992). Teachers sense of efficacy and commitment to teaching. Journal of Experimental Education, 60(4), 323-337.

Day, C., \& Gu, Q. (2007). Variations in the conditions for teachers' professional learning and development: Sustaining commitment and effectiveness over a career. Oxford Review of Education, 33(4), 423-443. https://doi.org/10.1080/03054980701450746. 
Day, C., \& Gu, Q. (2014). Resilient teachers, resilient schools: Building and sustaining quality in testing times. Oxon, UK: Routledge.

DeWert, M. H.; Babinski, L. M., \& Jones, B. D. (2003). Safe passagespassages: Providing online supportonline support to beginning teachers beginning teachers. Journal of Teacher Education, 54(4), 311-320. https://doi.org/10.1177/0022487103255008.

European Commission, (2010). Developing coherent and system-wide induction programmes for beginning teachers. A handbook for policymakers. European Commission Staff Working Document. SEC(2010) 538 final [pdf]. http://ec.europa.eu/dgs/education_culture/repository/educat ion/policy/school/doc/handbook0410_en.pdf. Accessed 10 Jul 2019.

European Commission/EACEA/Eurydice (2018). La profesión docente en Europa: Acceso, progresión y apoyo. Informe de Eurydice. Luxemburgo: Oficina de Publicaciones de la Unión Europea.

Greenlee, B. J., \& Dedeugd, I. S. (2002). From hope to despair: the need for beginning teacher advocacy. Teacher Development, 6(1), 63-74.

Gu, Q., \& Day, C. (2013). Challenges to teacher resilience: Conditions count. British Educational Research Journal, 39(1), 22-44. https://doi.org/10.1080/01411926.2011.623152.

Ingersoll, R., \& Smith, T. M. (2004). Do teacher induction and mentoring matter? https://reposi tory.upenn.edu/gse_pubs/134. Accessed 8 July 2019.

Ingersoll, R. M., \& Strong, M. (2011). The impact of induction and mentoring programs for begnning teachers: A critical review of the research. Review of Educational Research, 81, 201-233. https:// doi.org/10.3102/0034654311403323.

Kelley, L. M. (2004). Why induction matters. Journal of Teacher Education, 55(5), 438-448. https:// doi.org/10.1177/0022487104269653.

Kessels, C. (2010). The influence of induction programs on beginning teacher's well being and professional development. Netherlands Organisation for Scientific Research. https://www.voion. nl/downloads/4eaec176-5310-40d0-8bb0-e95ca72aaef3. Accessed 5 July 2019.

Kyriacou, C. (2010). Conceptualising teacher resilience in relation to stress. Paper presented at an ESRC invitational seminar on teacher resilience held at the University of Oxford, UK.

Leroux, M., \& Théorêt, M. (2014). Intriguing empirical relations between teachers' resilience and reflection on practice. Reflective Practice: International and Multidisciplinary Perspectives, 15(3), 289-303. https://doi.org/10.1080/14623943.2014.900009.

Leroux, M. (2018). Exploring Canadian early career teachers' resilience from an evolutionary perspective. In M. Wosnitza, F. Peixoto, S. Beltman, \& C. F. Mansfield (Eds.), Resilience in education: Concepts, contexts and connections (pp. 107-130). Cham: Springer.

Marcelo García, C. (2009). Profesores principiantes y programas de inducción a la práctica docente. Enseñanza \& Teaching: Revista Interuniversitaria de Didáctica. http://revistas.usal.es/index.php/ 0212-5374/article/view/3365. Accessed 5 July 2019.

Mansfield, C. F., Beltman, S., Price, A., \& McConney, A. (2012). "Don't sweat the small stuff": Understanding teacher resilience at the chalkface. Teaching and Teacher Education, 28, 357-367. https://doi.org/10.1016/j.tate.2011.11.001.

Mansfield, C. F., Beltman, S., Broadley, T., \& Weatherby-Fell, N. (2016). Building resilience in teacher education: An evidenced informed framework. Teaching and Teacher Education, 54, 77-87. https://doi.org/10.1016/j.tate.2015.11.016.

Ministry of Education, Culture and Sport (MECD) (2018). Datos y cifras: Curso escolar 201819. [Facts and figures: school year 2018-19]. Madrid: SecretaríaTécnica General. Retrieved from http://www.educacionyfp.gob.es/dam/jcr:f17caadd-acf4-41e5-8143-8489ed4b0cf2/datosy cifras1819esp.pdf.

Morgan, M. (2011). Resilience and recurring adverse events: testing an assets-based model of beginning teachers' experiences. The Irish Journal of Psychology, 32(3-4), 92-104. https://doi. org/10.1080/03033910.2011.613189.

OECD. (2017). Initial Teacher Preparation Study. Retrieved from http://www.oecd.org/education/ school/talis-initial-teacher-preparation-study.htm. 
Panigua, A., \& Sánchez-Martí, A. (2018). Early Career Teachers: Pioneers triggering innovation or compliant professionals? OECD Education Working Papers No. 190.

Pedró, F., Lloret, T., Carrasco, S., Plandiura, R., Mominó, J. M., et al. (2008). El professorat de Catalunya [Faculty of Catalonia]. Barcelona: Fundació Jaume Bofill.

Rots, I., Aelterman, A., Vlerick, P., \& Vermeulen, K. (2007). Teacher education, graduates' teaching commitment and entrance into the teaching profession. Teaching and Teacher Education, 23(5), 543-556. https://doi.org/10.1016/j.tate.2007.01.012.

Silva, J. C., Pipa, J., Breuer, C., O’Donnell, M., \& Cefai, C. (2018). Enhancing teacher's resilience through face-to-face training-Insights from ENTREE project. In M. Wosnitza, F. Peixoto, S. Beltman, \& C. F. Mansfield (Eds.), Resilience in education: Concepts, contexts and connection (pp. 255-274). Cham: Springer.

Skaalvik, E. M., \& Skaalvik, S. (2011). Teacher job satisfaction and motivation to leave the teaching profession: Relations with school context, feeling of belonging, and emotional exhaustion. Teaching and Teacher Education, 27, 1029-1038. https://doi.org/10.1016/j.tate.2011.04.001.

Stromquist, N. P. (2018). La situación del personal y la profesión docente en el mundo. Investigaciones Internacional de la Educación.

Tait, M. (2008). Resilience as a contributor to novice teacher success, commitment, and retention. Teacher Education Quarterly, 35(4), 57-75.

TALIS. (2013). Estudio internacional de la enseñanza y el aprendizaje. Informe español. Ministerio de Educación, Cultura y Deporte. https://www.educacionyfp.gob.es/inee/dam/jcr:530e4938f6c5-446c-937c-4c9df0a37481/talispublicacionessep2014.pdf. Accessed 30 Jun 2019.

TALIS (2018). Estudio internacional de la enseñanza y el aprendizaje. Informe español. Ministerio de Educación, Cultura y Deporte. https://www.educacionyfp.gob.es/inee/dam/jcr:64214edb9db9-4730-9be9-6d8cf7ed0f13/talis-2018-online-2-1.pdf. Accessed 30 Jun 2019.

Ungar, M. (2012). Social ecologies and their contribution to resilience. In M. Ungar (Ed.), The social ecology of resilience: A handbook of theory and practice (pp. 13-32). New York: Springer. https://doi.org/10.1007/978-1-4614-0586-3_2.

Vicente de Vera, I. (2017). Evaluación del burnout y factores de resiliencia-engagement en docentes. Doctoral dissertation, Pamplona, Spain: Universidad Pública de Navarra.

Wosnitza, M., Delzepich, R., Schwarze, J., O'Donnell, M., Faust, V., \& Camilleri, V. (2018). Enhancing teacher resilience: From self-reflection to training. In M. Wosnitza, P. Peixoto, S. Beltman, \& C. F. Mansfield (Eds.), Resilience in education: Concepts, contexts and connections (pp. 275-288). Cham: Springer.

Open Access This chapter is licensed under the terms of the Creative Commons Attribution 4.0 International License (http://creativecommons.org/licenses/by/4.0/), which permits use, sharing, adaptation, distribution and reproduction in any medium or format, as long as you give appropriate credit to the original author(s) and the source, provide a link to the Creative Commons license and indicate if changes were made.

The images or other third party material in this chapter are included in the chapter's Creative Commons license, unless indicated otherwise in a credit line to the material. If material is not included in the chapter's Creative Commons license and your intended use is not permitted by statutory regulation or exceeds the permitted use, you will need to obtain permission directly from the copyright holder.

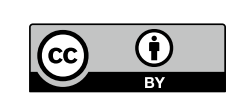

